\title{
Efeito de níveis de uréia sobre o valor nutricional do feno de capim-Tanzânia
}

\section{Effect of urea levels on the nutritional value of Tanzania-grass hay}

\author{
Anderson de Moura Zanine ${ }^{1 *}$; Edson Mauro Santos ${ }^{1}$; \\ Daniele de Jesus Ferreira' ${ }^{2}$; Odilon Gomes Pereira ${ }^{3}$
}

\begin{abstract}
Resumo
O experimento foi desenvolvido objetivando-se avaliar o efeito da adição de uréia em doses crescentes, sobre o valor nutritivo do feno de capim-Tanzânia (Panicum maximum, Jacq cv. Tanzânia). O delineamento experimental foi o inteiramente casualizado, com quatro tratamentos: $\mathrm{T} 1$ - somente feno, $\mathrm{T} 2$ - feno mais $1,0 \%$ de uréia, T3 - feno mais 2,0\% de uréia e T4 - feno mais 3,0\% de uréia, com base na matéria seca, e dez repetições por tratamento. Houve efeito linear positivo dos níveis de uréia sobre o teor de proteína bruta (PB), com o maior nível proporcionando aumentos de quatro pontos percentuais em relação ao tratamento testemunha. O tratamento com uréia proporcionou, também, redução no teor da fibra em detergente neutro (FDN), fibra em detergente ácido (FDA) e hemicelulose (HEM), por meio de um comportamento linear negativo. Os valores obtidos pela equação de regressão na dose mais elevada foram 62,37, 38,74 e 23,66\%, para os valores de FDN, FDA e HEM, respectivamente. Houve efeito linear positivo para a digestibilidade com a adição dos níveis de uréia proporcionando aumentos médios de $53,93 \%$ na testemunha para $63,96 \%$, na dose de $3,0 \%$. O uso de uréia é eficiente em promover melhorarias na qualidade do feno de capim-Tanzânia.

Palavras-chave: Conservação, fibra, proteína degradável, parede celular, qualidade
\end{abstract}

\begin{abstract}
This experiment was developed to evaluate the effect of the urea addition on the nutritional value of the Tanzânia-grass hay (Panicum maximum, Jacq cv. Tanzânia). The experimental design was entirely randomized, with four treatments: $\mathrm{T} 1$ - only hay, $\mathrm{T} 2$ - hay with $1.0 \%$ of urea, $\mathrm{T} 3$ - hay with $2.0 \%$ of urea and T4 - hay with $3.0 \%$ of urea, with base in the dry matter, and ten replicates per treatment. There was positive linear effect of the urea levels on the crude protein $(\mathrm{CP})$, being the largest level providing increases of four percentile points in relation to the control treatment. This treatment provided, also, reduction in neutral detergent fiber (NDF), acid detergent fiber (ADF) and hemicelulose (HEM), through a negative lineal effect. The values obtained by the regression equation in the highest dose were 62.37, 38.74 and $23.66 \%$, to NDF, ADF and HEM values, respectively. There was positive linear effect for the digestibility with the addition of the urea levels providing medium increases of $53.93 \%$ in the control to $63.96 \%$ in the dose of $3.0 \%$. The urea use is efficient in promoting increment in the quality of the Tanzânia-grass hay.
\end{abstract}

Key words: Conservation, cell wall, degradable protein, fiber, quality

1 Doutorando em Zootecnia, Universidade Federal de Viçosa- UFV, Viçosa, MG, Bolsista do CNPq. E-mail: anderson.zanine@ibest.com.br

2 Graduanda em Zootecnia, Universidade Federal Rural do Rio de Janeiro- UFRRJ.

3 Professor Adjunto do Departamento de Zootecnia, Universidade Federal de Viçosa- UFV.

* Autor para correspondência 


\section{Introdução}

A alimentação de ruminantes é um importante componente econômico dentro do processo produtivo, de modo que alternativas para a suplementação, que reflitam na diminuição de custos, têm sido utilizadas. Os resíduos de culturas anuais de verão e de inverno, e os fenos, são normalmente utilizados na dieta de bovinos (FERNANDES et al., 2002).

Nos últimos anos, têm-se utilizado diversos tipos de tratamentos químicos, físicos e biológicos visando melhorar as características de volumosos para que possam ser melhor aproveitados pelos ruminantes (GOBBI et al., 2005). O tratamento químico com uréia reduz as barreiras físicas e químicas da digestão da parede celular, bem como incrementa o conteúdo de nitrogênio (DAMASCENO et al., 1994). Além de ser uma alternativa viável, por ser um produto com grande disponibilidade no mercado, de fácil aplicação com baixos riscos de intoxicação humana e, na maioria das vezes, menos oneroso que a amônia anidra (GOBBI et al., 2005).

Diversas pesquisas têm indicado que o tratamento de volumosos de baixa qualidade, utilizando-se fontes de amônia, pode melhorar a qualidade desses produtos, elevando significativamente seu valor nutritivo e, conseqüentemente, seu consumo e aproveitamento pelos animais (REIS; RODRIGUES; PEREIRA, 2001; GRANZIN; DRYDEN, 2003).

O tratamento químico de volumosos de baixo valor nutritivo resulta em elevação na digestibilidade da celulose e da hemicelulose, em razão da expansão das moléculas de celulose, devido ao rompimento das pontes de hidrogênio e aumento da hidratação da fibra, permitindo o rápido acesso dos microrganismos, o que resulta, conseqüentemente, em maior digestibilidade da matéria seca (DOLBERG, 1992; SCHIERE; NELL, 1993; BERGER; FAHEY JÚNIOR; BOURQUIM, 1994).

Vale destacar que a utilização da uréia como fonte de amônia apresenta fácil manuseio e baixo custo como destacado por Neiva e Garcia (1995), porém há carência de resultados de pesquisas para determinar o nível ótimo de adição de uréia (CÂNDIDO et al., 1999).

Objetivou-se com o trabalho avaliar o efeito da adição de níveis de uréia sobre as características relacionadas ao valor nutricional do feno de capim Tanzânia.

\section{Material e Métodos}

O experimento foi realizado no Departamento de Zootecnia da Universidade Federal de Viçosa, Viçosa-MG. A cidade de Viçosa está situada a $20^{\circ} \mathrm{e}$ $45^{\prime}$ de latitude sul, $42^{\circ}$ e $51^{\prime}$ de longitude oeste e 657 $m$ de altitude, apresentando precipitação média anual de $1341 \mathrm{~mm}$, dos quais cerca de $86 \%$ ocorrem nos meses de outubro a março.

Utilizou-se uma pastagem de capim- Tanzânia (Panicum maximum, Jacq cv. Tanzânia), recém formada com 70 dias de rebrotação, após o rebaixamento mecânico a uma altura de $25 \mathrm{~cm}$. Os valores das características químicas do solo da camada de 0-20 cm, de acordo com a análise se solo foram os seguintes: $\mathrm{pH}\left(\mathrm{H}_{2} \mathrm{O}\right)=6,60$; cálcio $=4,90$ $\mathrm{cmol} / \mathrm{dm}^{3} ;$ magnésio $=1,10 \mathrm{cmol} / \mathrm{dm}^{3} ;$ alumínio $=0,0$ $\mathrm{cmol} / \mathrm{dm}^{3}$; hidrogênio + alumínio $=1,65 \mathrm{cmol} / \mathrm{dm}^{3}$; capacidade de troca catiônica $=9,75 \mathrm{cmol} / \mathrm{dm}^{3}$; saturação por bases $=83 \%$; fósforo $=53,40 \mathrm{mg} / \mathrm{dm}^{3}$; potássio $=360 \mathrm{mg} / \mathrm{dm}^{3}$. Não houve necessidade de se fazer qualquer tipo de correção ou adubação da área para o plantio da gramínea, tendo em vista a elevada fertilidade apresentada pela área, bem como pelo alto valor do $\mathrm{pH}$ e o baixo valor do alumínio, apenas utilizou-se $50 \mathrm{~kg} / \mathrm{N} / \mathrm{h}$ a após o corte.

O delineamento experimental foi o inteiramente casualizado, com quatro tratamentos: T1 - somente feno, T2 - feno mais 1,0\% de uréia, T3 - feno mais $2,0 \%$ de uréia e $\mathrm{T} 4$ - feno mais $3,0 \%$ de uréia, com base na matéria seca, e dez repetições por tratamento.

O feno de capim Tanzânia foi misturado à quantidade de uréia correspondente a cada dose. A quantidade de água utilizada como veículo para a uréia 
foi de $50 \mathrm{ml}$. Esta quantidade foi aplicada inclusive no tratamento testemunha. Em seguida, efetuou-se a homogeneização. Esta mistura foi então colocada em sacos de polietileno com dimensões de $0,60 \mathrm{x}$ $0,90 \mathrm{~m}$ e espessura de $0,20 \mathrm{~mm}$. Os sacos, após o enchimento, foram vedados com fitas adesivas e armazenados em galpão coberto por período de 35 dias, como recomendado por Sundstol, Cox,wort e Mowat (1978). Então, retiraram-se amostras, que foram levadas à estufa a $55^{\circ} \mathrm{C}$ para pré-secagem, e posterior determinação das análises bromatológicas.
Nas amostras de feno, foram determinados os teores de matéria seca (MS), proteína bruta (PB), fibra em detergente neutro (FDN), fibra em detergente ácido (FDA), hemicelulose (HEM) e digestibilidade in vitro da MS (DIVMS) conforme o método de Van Soest, descrito por Silva e Queiroz (2002). Na Tabela 1, podem ser observados os valores dos constituintes bromatológicos do feno nas diferentes concentrações de uréia antes do armazenamento (dia da aplicação).

Tabela 1. Teores médios de matéria seca (MS), proteína bruta (PB), fibra em detergente neutro (FDN), fibra em detergente ácido (FDA), hemicelulose (HEM) do feno de capim-tanzânia (CT) tratado com diferentes níveis de uréia antes do armazenamento.

\begin{tabular}{lccccc}
\hline Tratamento & $\begin{array}{c}M S \\
(\%)\end{array}$ & $\begin{array}{c}P B \\
(\% M S)\end{array}$ & $\begin{array}{c}F D N \\
(\% M S)\end{array}$ & $\begin{array}{c}F D A \\
(\% M S)\end{array}$ & $\begin{array}{c}H E M \\
(\% M S)\end{array}$ \\
\hline CT & 42,01 & 6,40 & 67,40 & 38,00 & 29,40 \\
CT $+1,0 \%$ & 35,5 & 6,70 & 66,89 & 38,60 & 28,29 \\
CT $+2,0 \%$ & 33,5 & 6,60 & 69,00 & 38,85 & 30,15 \\
CT $+3,0 \%$ & 34,5 & 7,40 & 65,75 & 39,14 & 26,61 \\
\hline
\end{tabular}

Para a análise de $\mathrm{pH}$, foram coletadas subamostras de aproximadamente $25 \mathrm{~g}$, às quais foram adicionados $100 \mathrm{ml}$ de água, e, após repouso de duas horas, efetuou-se a leitura do $\mathrm{pH}$, utilizandose um potenciômetro (ASSOCIATION OF OFFICIAL ANALYTICAL CHEMISTS, 1999).

Os dados foram submetidos a análise estatística, utilizando-se o programa SAEG (UNIVERSIDADE FEDERAL DE VIÇOSA, 1999), versão 8.0 da Universidade Federal de Viçosa. Para estimar o efeito das várias doses sobre cada variável analisada utilizou-se regressão a 5\% de probabilidade.

\section{Resultados e Discussão}

Na Figura 1, podem ser observados a equação de regressão e o coeficiente de determinação da MS do feno de capim- Tanzânia. Observou-se que para os valores de MS houve efeito linear negativo $(\mathrm{P}<0,05)$, ou seja, à medida que se aumentou à dose de uréia na amonização houve uma redução na MS, obtendo-se na dose mais elevada de uréia $(3,0 \%)$ o menor valor $(39,40 \%)$. A redução nos teores de matéria seca de materiais amonizados pode ocorrer devido ao elevado poder higroscópico da uréia, fazendo com que o material absorva umidade do ambiente (CÂNDIDO et al., 1999).

Cândido et al. (1999) avaliando níveis crescentes de uréia na amonização no bagaço de cana-deaçúcar, observaram comportamento quadrático da equação, obtendo o maior valor na dose próxima de $6 \%$ de uréia. Entretanto, Sarmento et al. (1999) trabalhando com diferentes níveis de uréia não encontraram efeitos sobre o valor de MS. 


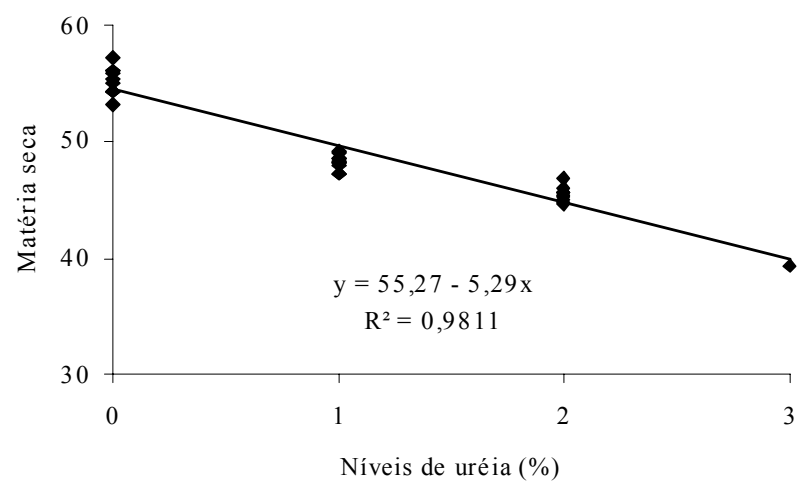

Figura 1. Equação de regressão e coeficientes de determinação $\left(\mathrm{R}^{2}\right)$ da matéria seca (MS) do feno de capimTanzânia tratado com diferentes níveis de uréia.

Houve efeito linear positivo $(\mathrm{P}<0,05)$ dos níveis de uréia para o teor de PB. Observa-se através da equação que o maior nível de uréia proporcionou aumentos de quatro pontos percentuais em relação ao tratamento testemunha (Figura 2). Reis et al. (2001) trabalhando com feno de gramíneas tropicais, também observaram aumentos médios nos teores de PB de 7,9 e 8,1\%, respectivamente, para os fenos amonizados com uréia (5,4\% da MS). Aumentos nos teores de PB para níveis crescentes de uréia também foram encontrados nos trabalhos realizados por Brown e Adjei (1995), Cândido et al. (1999) e Granzin e Dryden (2003), com feno de capim-Colonião, bagaço de cana e capim- Rhodes, respectivamente. Resultados semelhantes do efeito da uréia sobre a fração nitrogenada foram observados por Campos (1995), Reis, Rodrigues e Riggieri (1998) e Souza et al. (2001).

Bertipaglia et al. (2005) relataram os maiores teores de PB nos fenos de Brachiaria brizantha com $15 \%$ de umidade e tratados com uréia. Enquanto que Oliveira et al. (2005) observaram incremento de 6,0; 5,0 e 4,0 \% no valor de PB utilizando-se 5\% de uréia, em relação à testemunha, nas gramíneas braquiárias, colonião e elefante, respectivamente.

A adição de uréia proporcionou redução no teor da FDN, FDA e HEM havendo comportamento linear negativo $(\mathrm{P}<0,05)$ (Figuras 3,4 e 5$)$. Os valores obtidos por meio de equação de regressão na dose mais elevada foram de 62,37; 38,74 e 23,66\%, respectivamente. De acordo com Van Soest (1994), esta redução nos teores da fibra pode ser atribuída à solubilização parcial da fração da hemicelulose, celulose ou lignina da parede celular. Essas suposições baseiam-se no fato de que a maioria das forragens submetidas a esse tipo de tratamento não apresentam diminuição dos outros constituintes da parede celular e, quando isso ocorre, é, proporcionalmente, em menor escala (KLOPFENSTEIN, 1978; VAN SOEST; FERREIRA, 1984; VAN SOEST; MASON, 1991; JACKSON, 1997; ROSA; FADEL, 2001).

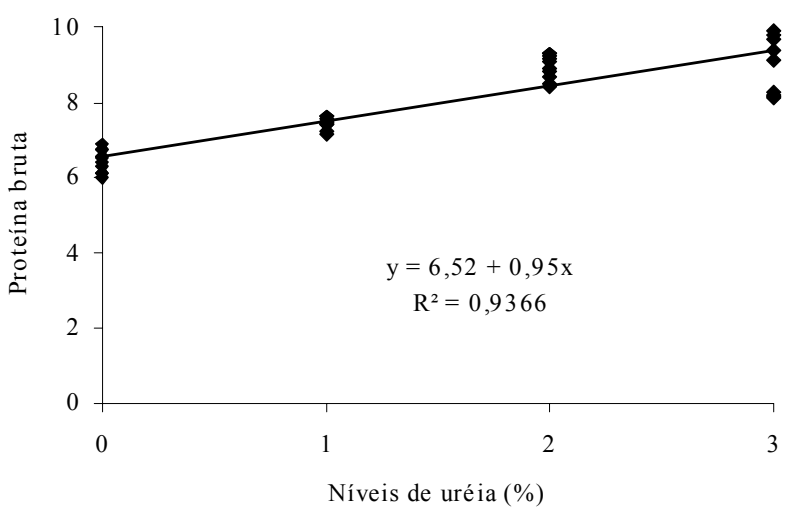

Figura 2. Equação de regressão e coeficientes de determinação $\left(\mathrm{R}^{2}\right)$ da proteína bruta $(\mathrm{PB})$ do feno de capim Tanzânia tratado com diferentes níveis de uréia.

Reis, Rodrigues e Resende (2001), Fernandes et al. (2002) e Granzin e Dryden (2003) trabalharam com amonização de fenos de capim-Braquiária e capim-de-Rhodes, respectivamente, e também observaram redução nos teores de FDN decorrente do tratamento dos volumosos com uréia.

Gobbi et al. (2005) utilizando diferentes níveis de uréia observaram redução no teor de FDA de forma linear negativa, registrando valor médio de 5\% no nível mais elevado em relação à testemunha. No presente experimento, a diferença foi de $2 \%$, pois utilizou-se menor dose de uréia. Esses mesmos autores descreveram para o teor de FDA resposta linear negativa até a dose de $10 \%$ de uréia. Com relação a HEM não foi observado efeito significativo 
para os níveis de uréia. Segundo Klopfenstein (1978), a redução no conteúdo de FDA nos materiais amonizados está associada à solubilização de lignina e celulose, presumidamente como um resultado da redução da cristalinidade da celulose e também em razão de sua expansão e da saponificação das ligações éster entre lignina e hemicelulose.

A utilização de uréia no tratamento de volumosos promove alterações na fração fibrosa com solubilização parcial da hemicelulose, resultando em diminuição no conteúdo de FDN (REIS et al., 1991; REIS; RODRIGUES; PEREIRA, 2001; ROSA; SOUZA; RODRIGUES, 2000; SCHIMIDT et al., 2003).

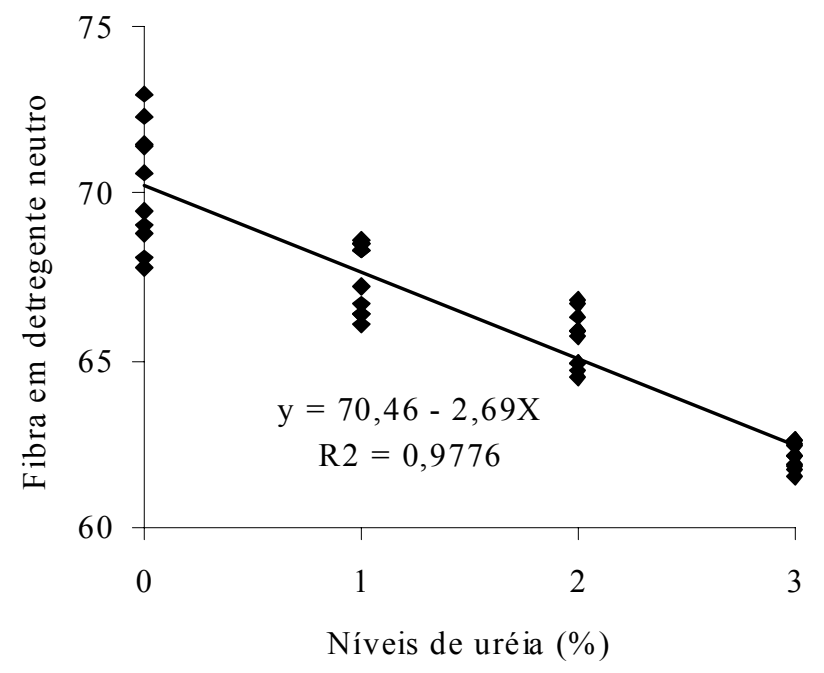

Figura 3. Equação de regressão e coeficientes de determinação $\left(\mathrm{R}^{2}\right)$ da fibra em detergente neutro $(\mathrm{FDN})$ do feno de capim Tanzânia tratado com diferentes níveis de uréia.

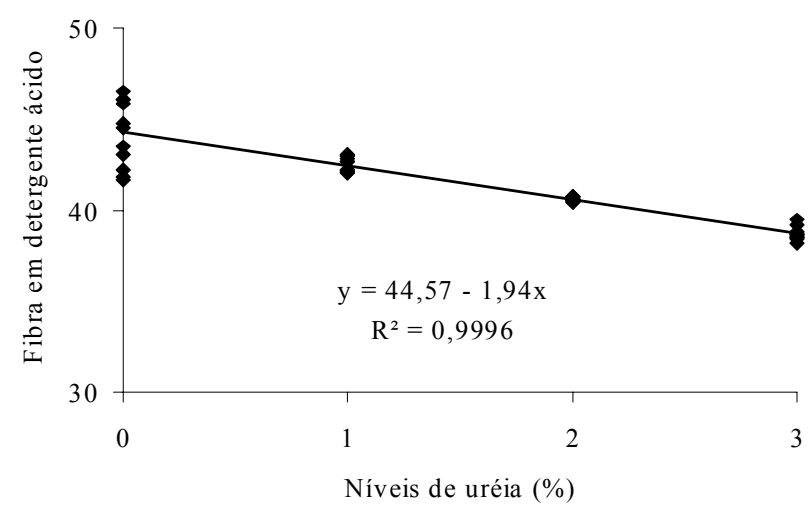

Figura 4. Equação de regressão e coeficientes de determinação $\left(\mathrm{R}^{2}\right)$ da fibra em detergente ácido (FDA) do feno de capim Tanzânia tratado com diferentes níveis de uréia.

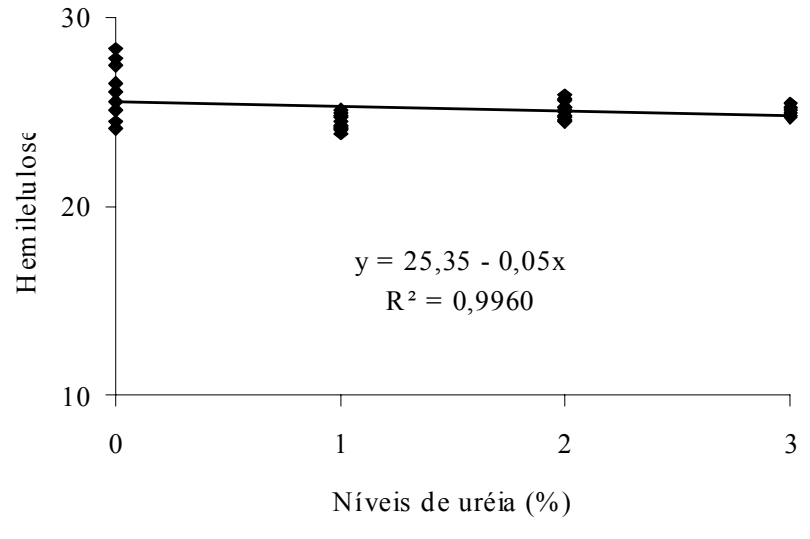

Figura 5. Equação de regressão e coeficientes de determinação $\left(\mathrm{R}^{2}\right)$ da hemicelulose (HEM) do feno de capim Tanzânia tratado com diferentes níveis de uréia.

$\mathrm{O}$ valor de $\mathrm{pH}$ apresentou resposta quadrática $(\mathrm{P}<0,05)$ aos níveis de uréia, estimando valor mínimo de 9,77 e 9,40 na dose mais elevada de acordo com a equação (Figura 6).

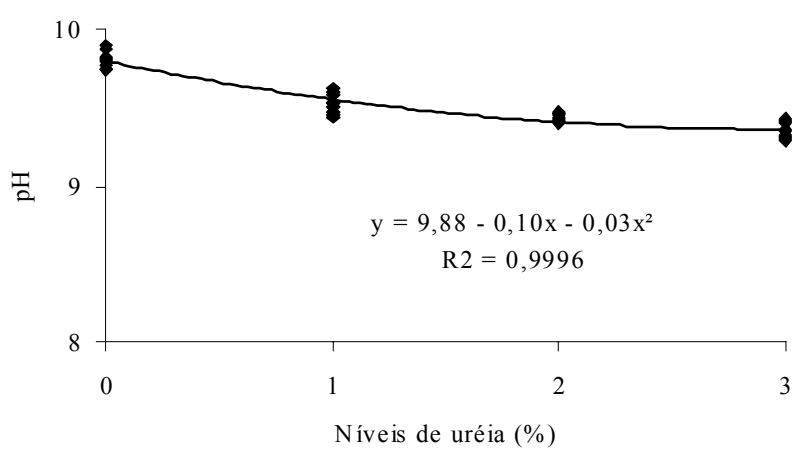

Figura 6. Equação de regressão e coeficientes de determinação $\left(\mathrm{R}^{2}\right)$ do valor de $\mathrm{pH}$ do feno capim Tanzânia tratado com diferentes níveis de uréia.

Foi observado efeito linear positivo para a DIVMS com a adição dos níveis de uréia (Figura 7). Pode ser observado aumento das médias na digestibilidade de $53,93 \%$, na testemunha, para $63,96 \%$ na dose de $3,0 \%$. A determinação da digestibilidade de forragens amonizadas é um procedimento considerado importante quando se pretende avaliar a eficiência da amonização, porque a degradação e o consumo de forragem estão, geralmente, correlacionados (GARCIA; PIRES, 1998). 
Reis (1995), estudando a amonização do feno de capim Brachiaria brizantha, verificaram aumento na DIVMS de 15,0\%, respectivamente para os fenos tratados com uréia.

Rosa et al. (1998) avaliando o valor nutritivo do feno de Brachiaria decumbens não tratado ou tratado com uréia (3,6 e 5,4\% da MS), observaram que a amonização aumentou a DIVMS. Os valores observados variaram de 52,93\% para o controle e 60,00 e $60,50 \%$ de DIVMS para o amonizado com os referidos níveis de uréia.

Reis et al. (2001) avaliando fenos de gramíneas tropicais, colhidos no estádio de maturação de sementes, não tratados ou tratados com uréia $(5,4 \%$ da MS), relataram que a amonização aumentou em média a DIVMS de 48,7 para $59,8 \%$ no Brachiaria decumbens, de 41,2 para 55,8\% no Brachiaria brizantha e de 46,8, para 56,4\% no capim Jaraguá, utilizando-se 5\% de uréia. Rocha et al. (2001), avaliando níveis de uréia $(0,2,4$ e $6 \%)$ em silagem de capim-elefante durante 60 dias de tratamento, verificaram alterações na DIVMS com valores de 41,$90 ; 52,30 ; 56,01$ e $55,02 \%$, respectivamente.

Oliveira et al. (2005) observaram para os tratamentos controle e para gramíneas tratada com 5\% uréia, valores de DIVMS de 55,5 e 69,2\% para capim Braquiária, 48,1 e 64,7\% para capim-Colonião, e 58,3 e $68,0 \%$ para o capim-Elefante, respectivamente.

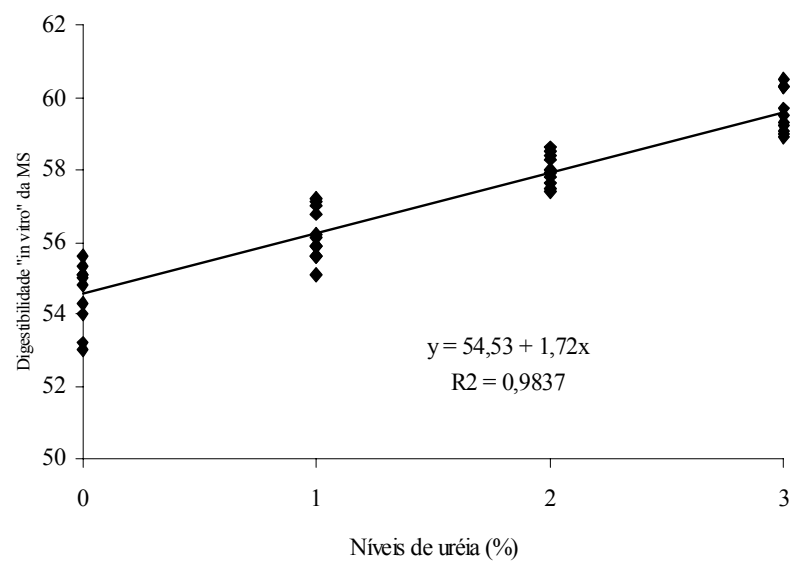

Figura 7. Equação de regressão e coeficientes de determinação $\left(\mathrm{R}^{2}\right)$ da digestibilidade in vitro da matéria seca (DIVMS) do feno de capim Tanzânia tratado com diferentes níveis de uréia.

\section{Conclusões}

O uso de uréia promove melhoria do valor nutricional do feno de capim-Tanzânia, por meio de redução da fração fibrosa, e aumento do teor de proteína bruta e da digestibilidade in vitro da matéria seca.

\section{Referências}

ASSOCIATION OF OFFICIAL ANALYTICAL CHEMISTS. Official methods of analysis. 15.ed. Washington: AOAC, 1999.

BERGER, L. L.; FAHEY JÚNIORR., G. C.; BOURQUIM, L. O. Modification of forage quality after harvest. In: FAHEY, J. R.; GEORGE, C. (Eds.). Forage quality, evaluation e utilization. Madison: American Society of Agronomy, 1994. p.922-966.

BERTIPAGLIA, L. M. A.; LUCA, S.; MELO, G. M.P.; REIS, R. A. Avaliação de fontes de urease na amonização de fenos de Brachiaria brizantha com dois teores de umidade. Revista Brasileira de Zootecnia, Viçosa, v.34, n.2, p.378-386, 2005.

BROWN, W. F.; ADJEI, M. B. Urea ammonization effects on the nutritive value of Guineagrass (Panicum maximum) hay. Journal of Animal Science, Champaign, v.73, p.30853093, 1995.

CAMPOS, M. C. L. Níveis de amônia anidra e períodos de amonização sobre a composição químicobromatológica e degradabilidade dos fenos de alfafa (Medicago sativa L.) e coast-cross (Cynodon dactylon (L.) Pers. cv. Coastcross) com alta umidade. 1995. Dissertação (Mestrado em Zootecnia) - Universidade Federal de Viçosa, Viçosa.

CÂNDIDO, M. J. D.; NEIVA, J. N. M.; PIMENTEL, J. C. M.; VASCONCELOS, V. R.; SAMPAIO, E. M.; NETO, J. M. Avaliação do valor nutritivo do bagaço de cana-deaçúcar amonizado com uréia. Revista Brasileira de Zootecnia, Viçosa, v.28, n.5, p.928-935, 1999.

DAMASCENO, J. C.; PRATES, E. R.; SILVA, C.S.; PIRES, F.F.; CURY, P.R. Efeito de níveis e formas de aplicação de uréia sobre a qualidade da palha de trigo. Revista Unimar, Maringá, v.16, n.1, p.137-147, 1994.

DOLBERG, F. Progressos na utilização de resíduos de culturas tratadas com uréia-amônia. In: SIMPÓSIO INTERNACIONAL EM RUMINANTES, n.1, 1992, Lavras. Anais... Lavras: SBZ, 1992. p.322-337. 
FERNANDES, L. O.; REIS, R. A; RODRIGUES, L. R. A.; LUDIC, I. L; MANZAN, R. J. Qualidade do feno de braquiária decumbens stapf. submetido ao tratamento com amônia anidra ou uréia. Revista Brasileira de Zootecnia, Viçosa, v.31,p.1325-1332, 2002.

GARCIA, R.; PIRES, J. N. M. Utilização da amonização na melhoria da qualidade de volumosos para ruminantes. In: SIMPÓSIO NORDESTINO DE ALIMENTAÇÃO DE RUMINANTES, 5., 1998, Salvador. Anais... Salvador: Sociedade Nordestina de Produção Animal, 1998. p.41-61.

GOBBI, K. F.; GARCIA, R.; GARCEZ NETO, A. F.; PEREIRA, O. G.; BERNARDINO, F. S.; ROCHA, F. S. Composição química e digestibilidade In Vitro do feno de Brachiaria decumbens Stapf. tratado com uréia. Revista Brasileira de Zootecnia, Viçosa, v.34, n.3, p.720-725, 2005.

GRANZIN, B. C.; DRYDEN, G. M. Effects of alkalis, oxidants and urea on the nutritive value of rhodes grass (Chloris gayana cv. Callide). Animal Feed Science and Technology, Amsterdam, v.103, n.1/4, p.113-122, 2003.

JAKCSON, M. G. Review article: the alkali tretment of straws. Animal Feeding Science Technology, Amsterdam, v.2, n.2, p.105-130, 1997.

KLOPFENSTEIN, T. J. Chemical treatment of crop residues. Journal of Animal Science, Champaign, v.46, n.3, p.841-848, 1978.

NEIVA, J. N. M.; GARCIA, R. Utilização da amonização na melhoria da qualidade de volumosos para ruminantes. In: SIMPÓSIO NORDESTINO DE ALIMENTAÇÃO DE RUMINANTES, 5., 1995, Salvador. Anais... Salvador: Sociedade Nordestina de Produção Animal, 1995. p.41-61.

OLIVEIRA, A. C.; PIRES, A. J. V.; OLIVEIRA, H. C.; PATES, N. M. S.; FONCECA, M. P.; MATOS NETO, U.; OLIVEIRA, U. L. C. Composição químico-bromatológica e digestibilidade in vitro de silagens de gramíneas tropicais tratadas com uréia. Revista Eletrônica de Veterinária, Montevideu, v.6, n.10, p.1-9, oct., 2005.

REIS, R. A0.; GARCIA, R.; QUEIROZ, A. C.; SILVA, D. J.; FERREIRA, J. Q. Efeitos da amonização sobre a qualidade do feno de gramíneas tropicais. Pesquisa Agropecuária Brasileira, Rio de Janeiro, v.26, n.8, p.1183-1191, 1991.

REIS, R. A. Sementes de gramíneas forrageiras. In: SIMPÓSIO SOBRE NUTRIÇÃO DE BOVINOS, 6., 1995, Piracicaba. Anais... Piracicaba: FEALQ, 1995. p.259-280.

REIS, R. A.; RODRIGUES, L. R. A.; RIGGIERI, A. C. Avaliação de fontes de amônia para o tratamento de fenos de gramíneas tropicais. In: REUNIÃO ANUAL DA SOCIEDADE BRASILEIRA DE ZOOTECNIA, 35., 1998, Botucatu. Anais... Botucatu: Sociedade Brasileira de Zootecnia, 1998. p.563-565.
REIS, R. A.; RODRIGUES, L. R. A.; PEREIRA, J. R. A. Composição química e digestibilidade de fenos tratados com amônia anidra ou uréia. Revista Brasileira de Zootecnia, Viçosa, v.30, n.3, p.666-673, 2001.

REIS, R. A.; RODRIGUES, L. R. A.; RESENDE, K. T. Avaliação de fontes de amônia para o tratamento de fenos de gramíneas tropicais. 1. Constituintes da parede celular, poder tampão e atividade ureática. Revista Brasileira de Zootecnia, Viçosa, v.30, n.3, p.682-686, 2001.

REIS, R. A; RODRIGUES, L. R. A; PEREIRA, J. R. A; RUGGIERI, A. C. Composição química e digestibilidade de fenos tratados com amônia anidra ou uréia. Revista Brasileira de Zootecnia, Viçosa, v.30, n.3, p.666-673, 2001.

ROCHA, F. C; GARCIA, R.; PEREIRA, O. G. P.; FREITAS, A. W. P.; BERNARDINO, F. S. Níveis de uréia e períodos de amonização sobre o valor nutritivo da silagem de capimelefante (Pennisetum purpureum Schum) - cv. Napier. In: REUNIÃO ANUAL DA SOCIEDADE BRASILEIRA DE ZOOTECNIA, 38., 2001, Piracicaba. Anais... Piracicaba: Sociedade Brasileira de Zootecnia, 2001. p.373-375.

ROSA, B.; FADEL, R. Uso de amônia anidra e de uréia para melhorar o valor alimentício de forragens conservadas. In: SIMPÓSIO SOBRE PRODUÇÃO E UTILIZAÇÃO DE FORRAGENS CONSERVADAS, 1 ., 2001, Maringá. Anais.... Maringá: UEM, 2001.p.41-63.

ROSA, B.; REIS, R. A.; RESENDE, K. T.; GARCIA, R. Valor nutritivo do feno de Brachiaria decumbens Stapf. cv. basilisk submetido a tratamento com amônia anidra e uréia. Revista Brasileira de Zootecnia, Viçosa, v.27, n.4, p.815822, 1998.

ROSA, B.; SOUZA, H.; RODRIGUES, K. F. Composição química do feno de Brachiaria brizantha cv. Marandu tratado com diferentes proporções de uréia e de água. Ciência Animal Brasileira, Goiânia, v.1, n.2, p.107-113, 2000.

ROSA, B; REIS, R. A; RESENDE, K. T.; KRONKA, S. N.; JOBIM, C. C. Valor nutritivo do feno de Brachiaria decumbens Stapf. cv. Basilisk submetido a tratamento com amônia anidra ou com uréia. Revista Brasileira de Zootecnia, Viçosa, v.27, p.815-822, 1998.

SARMENTO, P.; GARCIA, R.; PIRES, A. J. V.; NASCIMENTO, A. Tratamento do bagaço de cana-deaçúcar com uréia. Revista Brasileira de Zootecnia, Viçosa, v.28, n.6, p.1203-1208, 1999.

SCHIERE, J. B.; NELL, A. J. Feeding of urea treated straw in the tropics. I. A review of its technical principles and economics. Animal Feed Science Technology, Amsterdam, v.43, n.2, p.135-147, 1993. 
SCHMIDT, P; WECHSLER, F. S.; VARGAS JÚNIOR, F. M.; ROSSI, P. Valor nutritivo do feno de braquiária amonizado com uréia ou inoculado com Pleurotus ostreatus. Revista Brasileira de Zootecnia, Viçosa, v.32, n.2, p.2040-2049, 2003.

SILVA, D. J.; QUEIROZ, A. C. Análise de alimentos: métodos químicos e biológicos. 3.ed. Viçosa: UFV Universitária, 2002.

SOUZA, A.C.L.; SILVA, J.F.C.; VASQUEZ, H.M. Efeito de fontes e níveis de amônia sobre a composição bromatológica da fração fibrosa em subprodutos da canade-açúcar. In: REUNIÃO ANUAL DA SOCIEDADE BRASILEIRA DE ZOOTECNIA, 36., Porto Alegre, 2001. Anais... Porto Alegre: SBZ, 1999.
SUNDSTOL, F.; COXWORT, E.; MOWAT, D. N. Mejora del valor nutritivo de la paja mediante tratamiento com amoniaco. Revista Mundial de Zootecnia, Roma, v.26, n.1, p.13-21, 1978.

UNIVERSIDADE FEDERAL DE VIÇOSA. Sistema de análises estatísticas e genéticas. Viçosa: SAEG. 1999. (Manual do usuário, versão 8.0).

VAN SOEST, P. J. Nutritional ecology of the ruminant. Ithaca: Cornell University Press, 1994.

VAN SOEST, P. J.; FERREIRA, A. M. Chemical properties of fiber in relation to nutritive quality of ammonia treated forages. Animal Feed Science and Technology, Amsterdam, v.10, n.2, p.156-164, 1984.

VAN SOEST, P. J.; MASON, V. C. The influence of Maillard reaction upon the nutritive value of fibrous feeds. Animal Feed Science and Technology, Amsterdam, v.32, n.1/3, p.45-53, 1991. 